\title{
JNPH
}

Volume 6 No. 2 (Oktober 2018)

(C) The Author(s) 2018

\section{UJI DAYA HAMBAT EKSTRAK BAWANG PUTIH (ALLIUM SATIVUM) TERHADAP SALMOENELLA TYPHI}

\author{
IMPACT TEST OF GARLIC EXTRACT (ALLIUM SATIVUM) ON \\ SALMONELLA TYPHI
}

JON FARIZAL

DOSEN DIII ANALIS KESEHATAN POLTEKKES KEMENKES BENGKULU

E-mail : jonfarizal77@gmail.com

\begin{abstract}
ABSTRAK
Latar belakang: Salah satu penyakit yang timbul akibat infeksi bakteri patogen yaitu demam tifoid atau thypoid fever. Thypoid disebabkan oleh infeksi bakteri Salmonella thypi. Bakteri yang masuk dalam golongan gram negatif, bakteri tersebut menyerang usus halus dan menyebabkan penyakit endemik di indonesia (Noriko et al., 2014). Menurut Kemenkes RI (2012), kasus demam tifoid dan paratipoid yang terjadi di indonesia berada diperingkat ke-3 dengan jumlah kasus sekitar 41.000 pasien yang dirawat inap dirumah sakit selama tahun 2010 dengan kasus meninggal sebanyak 274 pasien. Alisin merupakan komponen sulfur bioaktif utama yang terkandung dalam bawang putih. Komponen ini hanya akan muncul apabila bawang putih dipotong atau dihancurkan. Tujuan penelitian : Untuk mengetahui besar daya hambat ekstrak bawang putih (Allium sativum) terhadap salmonella typhi.Metode penelitian : jenis penelitian ini menggunakan desain survei deskriftif untuk mengetahui besar daya hambat ekstrak bawang putih terhadap bakteri Salmonella thypi. Penelitian ini menggunakan bakteri Salmonella typhi yang diberi perlakuan esktrak bawang putih dengan konsentrasi $100 \%, 75 \%$, $50 \%$, dan $25 \%$.Hasil penelitian : Konsentrasi yang terbentuk zona hambat pertumbuhan bakteri Salmonella thypi yaitu konsentrasi $100 \%$ dan $75 \%$ rata-rata $9,7 \mathrm{~mm}$ dan $8,7 \mathrm{~mm}$ sedangkan pada konsentrasi $50 \%$ dan 25\% tidak terbentuk zona hambat. Kesimpulan : bahwa ekstrak bawang putih dapat digunakan sebagai alternatif pengobatan terhadap infeksi bakteri Salmonella typhi.
\end{abstract}

\section{Kata Kunci : Salmonella thypi, Bawang Putih.}

\begin{abstract}
Background: One of the diseases arising from pathogenic bacterial infection that typhoid fever or typhoidfever.Typhoid caused bybacteria infection Salmonellathypi.Bacteria are included in the group of gram-negative bacteria attacks the small intestine and cause disease endemic in Indonesia (Noriko etal.,2014). According to the Indonesian Ministry of Health (2012), cases of typhoid fever and paratipoid happened in Indonesia was rated 3rd in the number of cases of about 41,000 hospitalized patients hospitalized during 2010 with the case of as many as 274 patients died. Alisin is the main bioactive sulfur compounds contained in garlic. This component will only appear when garlic is cut or crushed. Objective: Was to determine the inhibitory large extracts of garlic(Alliumsativum)against salmonellatyphi.Methods: The design of this type of
\end{abstract}


research descriptive survey to determine the inhibitory large garlic extract against bacteria Salmonellathypi.This study usingbacteria Salmonella typhi treated with extract of garlic with a concentration of $100 \%, 75 \%, 50 \%$ and $25 \%$.Results: The concentration of growth inhibition zone formedbacteria thypiSalmonella namelyconcentration of $100 \%$ and $75 \%$ on average 9.7 $\mathrm{mm}$ and $8.7 \mathrm{~mm}$ and in a concentration of $50 \%$ and $25 \%$ are not formed inhibitory zone. Conclusions : that garlic extract can be used as an alternative treatment against bacterial infections Salmonellatyphi.

\section{Keywords : Salmonella thypi, Garlic.}

\section{PENDAHULUAN}

Salah satu penyakit yang timbul akibat infeksi bakteri patogen yaitu demam tifoid atau typhoid fever. Tyhpoid disebabkan oleh infeksi bakteri Salmonella typhi. Bakteri yang termasuk dalam golongan gram negatif, bakteri tersebut menyerang usus halus dan menyebabkan penyakit endemik di indonesia (Noriko et al., 2014).

Menurut Kemenkes RI (2012), kasus demam tifoid dan paratipoid yang terjadi di indonesia berada diperingkat ke-3 dengan jumlah kasus sekitar 41.000 pasien yang dirawat inap dirumah sakit selama tahun 2010 dengan kasus meninggal sebanyak 274 pasien. Penyebab dari penyakit demam tipoid yaitu adanya infeksi bakteri salmonella paratyphii $B$, salmonella paratyphii $A$ atau salmonella typhi ke dalam tubuh manusia. Namun, pada umumnya spesies yang menyebabkan penyakit demam tifoid ini adalah salmonella typhi(Nadifah, Yulianan and Reni, 2016).

Penggunaan obat-obatan herbal yang berasal dari tumbuhan dan rempah, apabila dibandingkan dengan obat-obatan yang diformulasikan dari bahan kimia, memiliki efek samping yang lebih minimal. Obatobatan herbal ini juga dapat dibeli dengan harga yang relatif murah, sehingga dengan mudah dapat dijangkau oleh kalangan sosial ekonomi manapun. Oleh karena itu, beberapa tahun belakangan ini, karena manfaatnya yang dinilai tinggi, penggunaan obat-obatan herbal yang berasal dari tumbuhan dan rempah meningkat(Moghadam, Navidifar and Amin, 2014).

Komponen utama dalam bawang putih yang dipercaya bertanggung jawab atas potensi antibakteri dan potensi terapeutik lain pada bawang putih ialah kandungan sulfur dalam bawang putih. Diantaranya ialah Diallythiosulfat (Allicin) dan juga Diallydisulfide (Ajone). Zat allicin adalah komponen aktif utama bawang putih. Pertama kali dilaporkan oleh CJ Cavalito pada tahun 1944, zat aliicin adalah bahan utama yang bertanggung jawab atas spektrum luas dari aktivitas antibakteri dalam bawang putih (Moghadam, Navidifar and Amin, 2014).

Alisin merupakan komponen sulfur bioaktif utama yang terkandung dalam bawang putih. Komponen ini hanya akan muncul apabila bawang putih dipotong atau dihancurkan. Pada saat bawang putih dihancurkan atau dipotong. Pada saat bawang putih dihancurkan, kerusakan membrane sel bawang putih ini akan mengaktifkan enzim ellinase, yang akan membantu proses metabolisme alliin yang terkandung dalam sel lain, menjadi allicin.

\section{METODE PENELITIAN}

Jenis penelitian adalah survey deskriptif. Dalam penelitian ini survey diskriptif digunakan untuk melihat adanya zona hambat ekstrak bawang putih (Allium sativum) terhadap Salmonella typhi. Variabel pada penelitian ini adalah ekstrak bawang putih (Alliun sativum) terhadap Salmonella typhi.

\section{HASIL PENELITIAN}

Hasil zona hambat yang terbentuk pada ekstrak bawang putih yaitu dengan 
terbentuknya zona bening pada medium pertumbuhan bakteri Salmonella typhi. Pada perlakuan konsentrasi ekstrak bawang putih $100 \%$ zona pada setiap pengulangan yaitu 9,6 $\mathrm{mm}, 9,0 \mathrm{~mm}, 9,7 \mathrm{~mm}, 9,0 \mathrm{~mm}$, rata-rata 9,3 mm dengan kategori sedang. Pada perlakuan konsentrasi ekstrak bawang putih $75 \%$ zona hambat pada setiap pengulangan yaitu 8,9 $\mathrm{mm}, 8,7 \mathrm{~mm}, 8,7 \mathrm{~mm}, 8,8 \mathrm{~mm}$, rata-rata pada setiap pengulangan yaitu $8,7 \mathrm{~mm}$ dengan kategori lemah.

\section{PEMBAHASAN}

Pada perlakuan konsentrasi ekstrak bawang putih $50 \%$ tidak memiliki zona hambat dalam menghambat pertumbuhan bakteri Salmonella typhi. Pada perlakuan konsentrasi ekstrak bawang putih $25 \%$ tidak memiliki zona hambat dalam menghambat pertumbuhan bakteri Salmonella typhi.Penelitian ini menggunakan kontrol negatif (-) yaitu Aquadest dan Kontrol positif $(+)$ kloramfnikol $100 \mathrm{mg}$ yang digunakan sebagai pembanding.

\section{KESIMPULAN}

Berdasarkan hasil penelitian uji daya hambat ekstrak bawang putih (Allium sativum) terhadap Salmonella typhi dapat disimpulkan pada konsentrasi $100 \%$ dan $75 \%$ terdapat zona hambat dengan rata-rata 9,3 $\mathrm{mm}$ dan $8,7 \mathrm{~mm}$, sedangkan pada konsentrasi $50 \%$ dan $25 \%$ tidak memiliki daya hambat.

\section{SARAN}

Dari penelitian tersebut dapat disarankan kepada masyrakat untuk dapat menggunakan bawang putih sebagai tanaman obat alternatif Salmonella typhi untuk demam tifoid dengan cara merebus bawang putih sebanyak 100 gram dalam $100 \mathrm{ml}$ air.

\section{DAFTAR PUSTAKA}

Adebolu, T. T., Adeoye, O. O. and Oyetayo, V. O. (2011) 'Effect of garlic (Allium sativum) on Salmonella typhi infection, gastrointestinal flora and hematological parameters of albino rats', African Journal of Biotechnology, 10(35), pp.6804-6808.

doi: 10.5897/AJB10.2598.

AgroMedia, R. (2007) Memanfaatkan Pekarangan untuk Taman Obat Keluarga. Jakarta Selatan.

Cassia siamea' (2013), pp. 1-28.

Cita, Y. P. (2011) Bakteri salmonella typhi dan demam tifoid', jurnal kesehatan masyarakat, 6(Vi), pp. 42-46.

Darmawati,S.(2009) keanekaragaman genetik Salmoella thypi',Jurnal Kesehatan, 2 (Juni), pp. 27-33.

David Roser (2005) bawang putih.pdf.

Fuadah, A., Sumarlan, S. H. and Hendrawan, Y.(2014) 'Kajian Pembuatan Bumbu Dari Bawang Putih (Allium sativum) Dan Daun Jeruk Purut (Cytrus hystrix) Menggunakan Pengering Tipe Rak The Study Of Making Flavor From Garlic (Allium sativum) And Kaffir Lime Leaves (Cytrus hystrix) Using The Dryer Rack Typ', jurnal keteknikan pertanian tropis dan biosistem, 2(2), pp. 156-166.

Harnani, S. J., Hiola, R. P. . and Amalia, L. (2013) 'uji efektifitas larutan bawang putih sebagai insektsida nabati untuk membunuh larva nyamuk aedes aegypti'.

Hartati, S. (2011) Gulma \& Rempah berkhasiat obat. 1st edn. bogor.

Indang, N., Guli, M. M. and Alwi, M. (2013) 'Uji Resistensi dan Sensitivitas Bakteri Salmonella thypi Pada Orang yang Sudah Pernah Menderita Demam Tifoid Terhadap Antibiotik', biocelebes, 7(1), pp. 27-34.

Indonesia, S. P. F. K. U. (1994) Buku ajar mikrobiologi kedokteran, Edisi Revisi. Jakarta: Binarupa Aksara.

Kiu, H., Kadir, S. and Saraswati, D. (2015) 'Ekstrak Bawang Merah dan Ekstrak Bawang Putih Sebagai Pengusir Nyamuk Culex sp yang Ramah 
Lingkungan', KIM Fakultas Ilmu-Ilmu Kesehatan dan Keolahragaan, 3(1).

Moghadam, F., Navidifar, T. and Amin, M. (2014) 'Antibacterial Activity of Garlic (Allium sativum L.) on Multi-Drug Resistant', Int J Enteric Pathog, 4, pp. 30-39. Available at:

http://enterpathog.com/27870.pdf. 